Lawrence University

Lux

$4-1-2013$

\title{
Brawling in the Library: Gaming Programs for Impactful Outreach and Instruction at an Academic Library
}

Angela M. Vanden Elzen

Lawrence University, angela.vandenelzen@lawrence.edu

Jacob Roush

Lawrence University, roush.jacob@gmail.com

Follow this and additional works at: http://lux.lawrence.edu/lib_pp

Part of the Educational Methods Commons, and the Library and Information Science Commons (C) Copyright is owned by the author of this document.

\section{Recommended Citation}

Vanden Elzen, Angela M. and Roush, Jacob, "Brawling in the Library: Gaming Programs for Impactful Outreach and Instruction at an Academic Library" (2013). Library Publications and Presentations. Paper 2.

http://lux.lawrence.edu/lib_pp/2

This Article is brought to you for free and open access by the Seeley G. Mudd Library at Lux. It has been accepted for inclusion in Library Publications and Presentations by an authorized administrator of Lux. For more information, please contact colette.brautigam@lawrence.edu. 


\title{
Brawling in the Library: Gaming Programs for Impactful Outreach and Instruction at an Academic Library
}

\author{
Angela M. Vanden Elzen and Jacob Roush
}

\begin{abstract}
Academic libraries not only need to focus on instructing students about library resources but also need to actively reach out to them. One way to accomplish this is to integrate gaming into library programming and instruction. The staff of the Lawrence University Seeley G. Mudd Library has been successfully incorporating games into library outreach programming. This article explores the various ways academic libraries have been integrating games into instruction and programming and provides advice and anecdotal evidence from programming experiences at the Seeley G. Mudd Library.
\end{abstract}

\section{INTRODUCTION}

Academic libraries not only need to focus on instructing students about library resources but also need to actively reach out to them. One way to accomplish this is to integrate gaming into library programming and instruction. A vast majority of today's college students have grown up with gaming as a part of their lives. The PEW Internet and American Life Study (Lenhart et al., 2008) reported that 97 percent of the teens polled stated they play video games regularly. Four years later, these teens are now college-aged. Not only have games become a mainstream part of daily life, but they are also becoming a more common tool in education. The 2012 Horizon Report named game-based learning as one of the six areas of emerging technology that will "have significant impact on higher education and creative expression over the next one to five years" (New Media Consortium \& EDUCAUSE Learning Initiative, 2012 abstract, pp. 18-21). By integrating games into library programming, library staff members gain the opportunity to reach students through new ways of library instruction, attract students who may not have taken the initiative to 
familiarize themselves with the library, and add to the university's sense of community. This article explores the variety of ways in which video games can be integrated into academic library programming with the goals of outreach and community enrichment, and also provides guidelines for doing so along with anecdotal support from the Seeley G. Mudd Library's experiences.

While the staff of the Seeley G. Mudd Library has been integrating board games and puzzles into library programming for many years, it was not until 2009 that we began to branch out and try a variety of different types of gaming programs in an attempt to reach a wider number of students. The Seeley G. Mudd Library is part of Lawrence University, a small liberal arts school in Appleton, Wisconsin. Because Lawrence University is a residential campus, we felt that the best way to reach out to our students was to add to the sense of community, while at the same time, increasing library awareness. By developing gaming programs that would bring students into the library for social purposes, we hoped that we would accomplish these goals.

A review of published literature shows that not only has the integration of games in academic libraries grown substantially in recent years but so have the methods of doing so. One such method is to turn library orientation into a game. Lizz Zitron and Courtney Drew of Carthage College created what they referred to as "a long, team-focused scavenger hunt," with the catchy name, Get a Clue, Carthage! (Zitron \& Drew, 2011, p. 637). At Fresno State University (Fusich, Dinscore, Smith, \& Vang, 2011), a group of librarians and students developed an online library orientation game, available to students through the university's course management system. Both reports indicated that students found the game-based orientations to be effective and engaging learning tools. Games have also been integrated into library information literacy instruction with reported success. Lycoming College librarian Mary J. Snyder Broussard (2010) and Maura A. Smale (2011) of the New York City College of Technology have written about their positive experiences using computer-based online games in information literacy instruction. Librarians at the University of Alabama libraries created an alternate reality game (Battles, Valerie, \& Lindley, 2011), ${ }^{1}$ using a variety of social media applications. Smale reported that integrating games into information literacy instruction "capitalizes on the many similarities between games and the way that students do research" (2011, p. 36). Another way in which games have been integrated into academic libraries is through library outreach programming. The D. H. Hill Library at NC State University (Williams \& Chimato, 2008) offers gaming events, such as Madden NFL tournaments and LAN parties in addition to permanent gaming stations in their learning commons. Librarians at the Z. Smith Reynolds Library at Wake Forest University offer open gaming nights as a way for new students to meet each other. By offering gaming 
events in the library, librarians are not only familiarizing students with the library but are gaining the opportunity to learn "more about our users and how to best serve them" (Levine, 2006, p. 40). Video games are among the variety of activities provided at the Helen C. White Library open house party (2011 Helen, 2011), which is hosted at the University of Wisconsin at Madison at the start of each school year. A number of libraries, including the Urbana-Champaign Library at the University of Illinois (Laskowski \& Ward, 2009), the Andersen Library at the University of Wisconsin at Whitewater (Weider, 2011), and the Science Library at the University of Oregon (Baker et al., 2008), to name a few, have added video games, consoles, and stations to their library collections. In the book Gaming in Academic Libraries: Collections, Marketing, and Information Literacy (Harris \& Rice, 2008), a wide variety of topics pertaining to games in libraries are covered. As the literature shows, academic libraries have been integrating games in a variety of ways.

\section{PARTnerships}

When planning gaming events in the library, there are many aspects to consider. Partnerships are an excellent way to make sure that a wide variety of students are reached, that the details of games are not overlooked, and that popular games are selected. Collaboration is an important part of creating successful gaming events. This can be accomplished by working with other departments or with students. Zitron and Drew (2011) of Carthage College created their gaming events through a joint effort of the library and student affairs. They explain that "collaborating to achieve shared goals around student programming enabled our departments to think and act bigger ... in order to create a high-quality program" ( $p$. 639). Libraries have also reported success in collaborating with the athletics program (O'English \& McCord, 2006), residence life (Cummings 2007), information technologies, and existing gaming-related student organizations (Sutton \& Womack, 2006).

Students who participate in gaming events may attend for fun and social interaction, but some are very serious about the rules and nuances of games. Lack of knowledge or expertise in a particular game by library staff can be a problem, not only because of the participants who are experts and expect certain rules to be followed, but also because a gaming event will not run smoothly if the coordinator is spending time trying to learn the rules, cannot answer participants' questions about the game, or has not prepared for the requirements of the game. The best way to overcome this challenge is for the library to ask enthusiastic and knowledgeable participants to help with the events. If the library is able to find a patron who is particularly skilled or knowledgeable about a certain game, chances are high that he or she will be not only willing but happy to help plan or 
facilitate an event. Another benefit is that participants are often willing to share their equipment and games in a well-supervised event.

Collaboration with student organizations is an excellent way to ensure that there is an audience for a particular event and that the event it will be organized by those who are knowledgeable about the game. Working with the library is also a way to help the student group increase their visibility on campus and recruit new members. After seeing the success of other library gaming events, a member of the campus Magic Club asked if the library would be interested in collaboratively planning a Magic: The Gathering event in the library. ${ }^{2}$ One challenge with Magic: The Gathering in libraries is that it is a collectable card game where players are expected to own their own cards. The club owned a large number of Magic cards, which allowed the event to be set up as a "cube draft" where all players select cards from a common club-owned pool. Magic Club president reported that this event had a larger participant turnout than any of their previous events. Many participants stated that the antique wood and metal cabinets, old books, and historical feel of the special-collections room where the event was held made for a fun atmosphere in which to play the card game based on imagination and magic. ${ }^{3}$

Simply speaking with students in the library can be a useful way to gain insight on what types of games are of interest to students on campus. While a certain game may be popular in the media, it does not necessarily mean that it is popular on a particular campus. For example, in 2009, the Mudd Library staff decided to plan a gaming tournament in celebration of National Library Week. The tournament was going to be either Rock Band or Guitar Hero. After speaking with a library student-worker, we learned that the popularity of those games had long since peaked on campus and that many students were playing Super Smash Bros. Brawl. We have found that this game is fast paced and easy to play (though player skill level varies greatly) and has proved to be an excellent choice for tournament play. While it is a fighting game, the cartoonish style and use of well-known characters from other video games make it accessible to a wide variety of participants as well as fun to watch. This game also has an established competitive scene, which provided us with standard tournament rules and structure. For our tournaments, we follow the Unity Ruleset as found on the website Smashboards.com. We typically offer a gift certificate as a prize to the winner, but participants have expressed that the best part of winning is the bragging rights associated with being the best Smash Bros. player on campus. These tournaments have experienced a substantial increase in attendance and enthusiasm since they have been planned and run collaboratively with the Lawrence University Gaming Club. As of May 2012, the library has hosted nine of these tournaments. 


\section{Planning}

When planning gaming programs, there will likely be challenges to overcome. Williams and Chimato report receiving "a number of negative comments from both students and faculty" in response to gaming programs in the D. H. Hill Library (2008, p. 72). When planning gaming events in an academic library, it is crucial to consult the academic calendar to make sure the events do not take place during times when students will be flocking to the library to study and write papers. The only times we have encountered patrons who have had negative reactions to gaming in the library is when we have planned events during busy times of the term, such as near final exams and mid-terms. Knowing this, we took special care when planning National Gaming in Libraries Day 2010 and 2011, which took place on the Saturday before final exams. We advertised it as a study break and were hoping it could be a way to offer a little time to relax and have fun between study sessions and, in this case, keep the activity level low. We set out a Nintendo Wii with The New Super Mario Bros., with the volume turned low, and a table with a small pile of board and card games. We observed multiple small groups of students playing for a short time, and then going back to work. Careful and considerate planning, with an awareness of academic demands, can lead to a well-received gaming program.

Lack of appropriate space for hosting gaming programs can prove to be a challenge. Ideally, a gaming space should be large enough for a crowd, be well lit, be located in an area that will allow participants to engage in a potentially noisy activity without disturbing library patrons, and have plenty of available power sources. At the Mudd Library, we do not have a designated space for library programming. We have taken advantage of the natural noisiness of the first floor near the circulation desk and entrance and used televisions on carts and folding tables to create impromptu spaces for board games and video games. These materials, along with movable armchairs and power strips, have helped us to create successful gaming events. As mentioned, we have also used one of our special-collections rooms, the Milwaukee-Downer Room, for a tabletop gaming event. The lighting in this room is not optimal for gaming, but the ambiance created a special experience for the participants.

Another obstacle in planning gaming events is obtaining the gaming equipment. If your library is planning an event with video games, there are a variety of ways to obtain the necessary equipment. Ideally, your library could purchase the necessary equipment, but that is not always practical or wise. If this is your first program, it may not be the best idea to rush out and spend hundreds of dollars. If you are collaborating on the program, the patron or student group with whom you are planning it may be able to provide what is needed. At the Mudd Library, we borrowed a Nintendo Wii from the local public library for our first video game program. Unfor- 
tunately, we learned the hard way that, when planning a tournament, it is crucial to make sure to look into whether characters, levels, and even menu options will need to be unlocked. "Unlocking" in video games is when special features of the game are made available as a result of gameplay. This is yet another reason why it is so helpful to consult with students when planning events. After many gaming events, we were able to set aside funds to purchase our own Nintendo Wii system, as well as a few games.

A drawback to the competitive nature and time demands of gaming tournaments is that it can be a barrier to those who are not highly skilled or do not have the time but still would like to play games in a social setting. One way to accommodate this type of patron is to offer an alternative. Alongside the tournament, the library staff can offer open gaming with an additional video game station, a table with board games, and even a jigsaw puzzle. At the Mudd Library, we have set up retro systems (brought in by library staff), such as the Nintendo Entertainment System from 1985, the Nintendo Wii with Mario Kart Wii, and the Xbox 360 with Mortal Kombat vs DC (a slightly less graphic version of Mortal Kombat). These stations do not see as heavy use as the ones in constant use for the tournament but are enjoyed by both tournament competitors and students who are interested in playing for fun or only for a short time.

When planning open gaming, it is important to consider how a patron will approach the event. If games are simply set up in the library, a patron may be reluctant to start playing and be the only person playing a game in the library. While open gaming can be set up in an inviting manner, it is best to schedule it in conjunction with another event or to have a staff person playing and inviting patrons to play along. During the summer of 2011, we offered open gaming on Friday afternoons for the students who were working on campus-many of whom worked for the grounds crew and were not scheduled to work on Friday afternoons. Along with the Nintendo Wii, we also set out a book cart of puzzles, board games, playing cards, and coloring books. While we found that this set up attracted very few participants, we did notice an unexpected outcome. By having a large selection of board games, video games, and even some popular movies on display, our patrons were able to see some of the lesser known items available at the library, which increased circulation.

As mentioned, open gaming can be a successful addition to a structured tournament, but it can also be a good addition to an open-housestyle event, at which many open events are scheduled. At the Mudd Library, our oldest tradition of gaming is a gaming day and open house we host for new freshmen during welcome week. Over the years, we have acquired a variety of board games, playing cards, puzzles, and coloring books to set out during these events. In recent years, we have set out the library's Nintendo Wii with games such as Mario Kart Wii, Mario Party 8, and The New Super Mario Bros. The library staff has been successful in making 
students feel more comfortable and welcomed by playing the video games and board games and inviting the students to play along. We also have also scheduled notebook and bookmark making and library tours along with gaming at the open houses.

Surveys are a useful way to generate feedback from event participants, as well as provide insights that can be useful for future events. We have found that SurveyMonkey.com is a useful tool for creating and sending online surveys. The results provided by SurveyMonkey are presented in a manner that is easy to interpret and collect. This product is free for a basic account; however, to extract their charts and graphs, one is required to purchase a subscription. Survey results have helped us to learn about things that participants wish we had done differently, better times in which to hold the events, games participants would like to see at future events, and more.

\section{Marketing}

Successfully advertising events so that they reach the target audience can be a challenge. One avenue that can be both useful and easy to use is social media. Librarians can use a variety of social media applications to ensure reaching out to the most students. Facebook provides a variety of page insights for page administrators, one of which provides the ages of those who follow (have liked) the page. After checking our page insights, we found that the majority of those who follow our page are over the age of 25. A majority of students at Lawrence University are between the traditional college ages of 18 to 21 . After noticing this, we realized that not only did we need to think of additional means of advertising but we also needed to think of a way to get more students to follow our page. We also realized that it was difficult to invite students to events, since those of us who are administrators for the page had only "friended" a small number of current students.

Speaking with students is an excellent way to learn about how students find out about events on campus. Event participants can be asked how they found out about the event and how they most often find out about other events on campus; however, this will not provide information from those students who did not attend the event. Library student workers are also an excellent resource. By speaking with students, we discovered that the online university calendar is printed out each morning and posted in the lobby of every residence hall. We now make sure that our events are submitted to the university calendar and have noticed not only an increase in attendance but also an increase in awareness of the library's outreach efforts in general.

In addition to modern methods of advertising, the old-fashioned method of hanging paper fliers can be very successful. Simply hanging a few fliers around the library will only reach a limited amount of stu- 
dents, who are likely already aware of the library's services. To reach students outside the library, we have estimated that at least fifty fliers need to be sent out to residence halls and academic buildings around campus. We were surprised to learn from event attendees that a large number reported that they had learned about the events from one of these fliers. Librarians at Fresno State University (Fusich et al., 2011) echoed this finding in a report about their library orientation game.

\section{IMPACT}

This report has explored the different ways in which academic libraries have integrated gaming into their instruction and programming, along with advice and anecdotal evidence to guide in the planning of gaming events. Why is gaming such an effective way to reach out to students? Today's undergraduates are often found to be overconfident in their research and information literacy skills. Articles such as "What Students Don't Know," have shown that "students rarely ask librarians for help, even when they need it" (Kolowich, 2011, n.p.). Research has shown that undergraduate students often "exhibited a lack of understanding of search logic" (Kolowich, 2011, n.p.). By reaching out to them with games, through library instruction or fun programming, librarians have an opportunity to connect the library with something that is relevant in many undergraduate students' lives.

The social aspect of gaming is also an excellent reason to integrate games into academic libraries. We believe that the immersive qualities and social aspects of games make them perfect for engaging students and creating an environment in which they can become comfortable. In their article "Out of the Basement: The Social Side of Gaming," Neiburger and Gullett explain that the shared experience of gaming "promotes the establishment of friendships among people with a common interest, and provides shared experiences they can fondly reflect upon" (2007, p. 35). This type of connection is especially important for a residential campus, such as Lawrence University.

By observing the students during library gaming events, and by speaking with library student assistants who participated, we could see that we were bringing students with shared interests, who may not have otherwise met, together. We also had empirical evidence of this fact after seeing the results of a survey we asked participants to fill out shortly after the first tournament in 2009. Fifty percent of respondents reported that they met new people with similar interests at the event. This outcome encouraged us to continue with gaming programs. In 2012, we sent another survey to those who participated in gaming events at the Mudd Library as well as those who were on the Lawrence University Gaming Club email list. In response to the question, "In what ways have the library gaming events altered your opinions on the following?" the most selected response (with 
76.9 percent selection rate) was "Gaming events have added to my sense of belonging in the Lawrence University Community" (fig. 1). Respondents were allowed to select multiple options for this question. We also found that well over half of our respondents reported that library gaming events have been either moderately, very, or extremely important to their overall Lawrence University experience. Our findings are consistent with findings from a 2003 study by the Pew Internet and American Life Project (Jones, et al., 2003), which studied gaming and college students. They found that 20 percent of students who game "felt moderately, or strongly that gaming helped them make new friends as well as improve existing friendships" (p. 2).

The Mudd Library's gaming events were an important factor in the establishment of the university's Gaming Club. The library's first few events led the club founders to realize that there was a high amount of interest in gaming on campus, and that it would only take a little more organization to form a club and host a wider variety of events throughout the term. Since its formation in the spring of 2011, the club has carried out events relating to a wide range of games. A few examples of events they have hosted are: improving skill in first-person shooter video games; how to manage a server for the PC game, Minecraft; an introduction to the card game, bridge; Magic: The Gathering draft for the charity, Child's Play; and many more. The 2011-2012 academic year is the first year that the Gaming Club was given student housing dedicated to gaming. Students who do not live in the house are encouraged to visit and play games, and can even apply to have a key so that they can enter when those who live in the house are at class. It has become a place for gamers from all over campus to spend time gaming, socialize about shared interests, and receive guidance from fellow gamers about how to balance gaming and academic demands. The university housing committee has been impressed with the community that has been built around gaming house and has increased their space from an eight-person house, to a twenty-four-person house.

Gaming events can not only bring students with similar interests together but also make students aware of library resources that they may find interesting for their course work. During our gaming events, we often place books that may be of interest on tables near the event. We set out books on games and education, creative writing, computer programming, art of video games, etc. During the 2011-2012 school year, Lawrence University began offering courses on new media, so we have also began to set out books on the topics of virtual worlds and new media. Since beginning this practice, we have noticed an increase in circulation of these books and have added a variety of new, related books to the library's collection. We also created a LibGuide, which includes a variety of gaming-related resources available in the library and on the Internet, as well as information about the variety of gaming events on campus. 


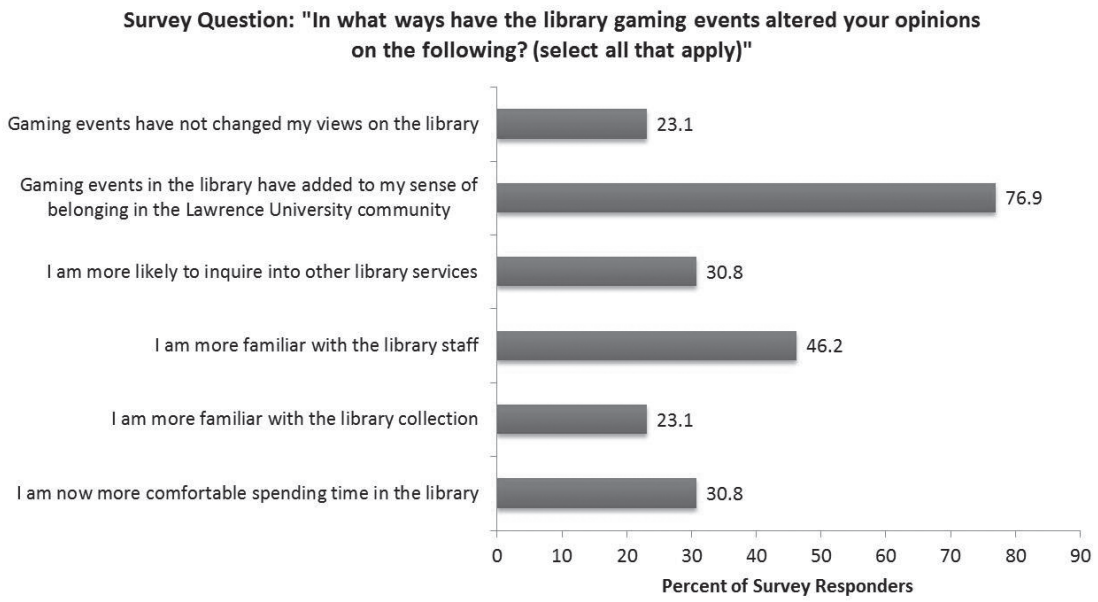

Figure 1. Graph of results from a 2012 survey conducted by the Seeley G. Mudd Library staff. (Source: Jacob Roush.)

Since we began hosting gaming events in the Seeley G. Mudd library, we have noticed a significant increase in the visibility of the library on campus. One student, who had attended gaming events, had been overheard telling a friend that "the library is the hippest place on campus." The topic of the conversation was not video games but the library's extensive selection of electronic databases. As we have mentioned, our survey results have shown that our events have added positively to our students' sense of belonging on campus and even added to their Lawrence University experience as a whole. We see the library as not only a place for research, but on an academic campus, the library is a second place for students. It is a place where they should feel at home and welcome. We feel that library gaming events have added to that feeling considerably.

\section{Notes}

1. Alternate reality games are described as "immersive, massively multiplayer experiences that unfold in the course of people's real lives" (McGonigal, 2008, p. 13).

2. Magic: The Gathering is a card-based competitive role-playing game published by Wizards of the Coast, LLC.

3. Many participants stated that the antique wood and metal cabinets, old books, and historical feel of the special-collections room where the event was held made for a fun atmosphere in which to play the card game based on imagination and magic.

\section{REFERENCES}

2011 Helen C. House Party. (2011). Retrieved June 19, 2012, from University of WisconsinMadison, College Library Web site: http://www.college.library.wisc.edu/news/featured/ houseparty11/ 


\section{LIBRARY TRENDS/SPRING 2013}

Baker, D., Barth, D., Nesselroad, L., Nigro, R., Robare, L., \& Zeidman-Karpinski, A. (2008). Lessons learned from starting a circulating videogame collection at an academic library. In A. Harris \& S. E. Rice (Eds.), Gaming in academic libraries: Collections, marketing, and information literacy (pp. 26-38). Chicago: Association of College and Research Libraries, A Division of the American Library Association.

Battles, J., Valerie, G., \& Lindley, S. (2011). Rethinking the library game: Creating an alternate reality with social media. Journal of Web Librarianship, 5(2), 114-131.

Broussard, M. J. S. (2010 January-March). Secret agents in the library: Integrating virtual and physical games in a small academic library. College $\mathcal{E}$ Undergraduate Libraries, 17(1), 20-30.

Cummings, L. U. (2007). Bursting out of the box: Outreach to the millennial generation through student services programs. Reference Services Review, 35(2), 285-295.

Fusich, M., Dinscore, A., Smith, K., \& Vang, V. (2011, December). HML-IQ: Fresno State's online library orientation game. College $\mathcal{E}$ Research Libraries News, 72, 626-630. Retrieved March 3, 2012, from http://crln.acrl.org/content/72/11/626.full.pdf+html

Harris, A., \& Rice, S. E. (Eds.) (2008). Gaming in academic libraries: Collections, marketing, and information literacy. Chicago: Association of College and Research Libraries, A Division of the American Library Association.

Jones, S., Clarke, L. N., Cornish, S., Gonzales, M., Johnson, C., Lawson, J. N., et al. (2003, July). Let the games begin: Gaming technology and college students. Pew Internet \& American Life Project. Retrieved March 16, 2012, from http://www.pewinternet.org/ /media// Files/Reports/2003/PIP_College_Gaming_Reporta.pdf.pdf

Kolowich, S. (2011, August 22). What students don't know. Inside Higher Ed. Retrieved May 1, 2012, from http://www.insidehighered.com

Laskowski, M., \& Ward, D. (2009, May). Perspectives on: Building next generation video game collections in academic libraries. The Journal of Academic Librarianship, 35(3), 267-273.

Lenhart, A., Kahne, J., Middaugh, E., Macgill, A., Evans, C., \& Vitak, J. (2008, September). Teens, video games, and civics. Pew Internet \& American Life Project. Retrieved April 2, 2012, from http://www.pewinternet.org/ /media//Files/Reports/2008/PIP_Teens _Games_and_Civics_Report_FINAL.pdf.pdf

Levine, J. (2006, September-October). Case studies: Academic libraries. Library Technology Reports. Gaming in Libraries: Intersection of Services, 42, 38-44.

McGonigal, J. (2008). Making alternate reality the new business reality. Harvard Business Review. Special Issue: Top 20 Breakthrough Ideas for 2008. Retrieved June 19, 2012, from http://janemcgonigal.com/learn-me/

Neiburger, E. \& Gullett, M. (2007 Winter). Out of the basement: The social side of gaming. Young Adult Library Services, 5, 34-38.

New Media Consortium \& EDUCAUSE Learning Initiative. (2012 February). 2012 Horizon Report. Retrieved May 1, 2102, from http://www.educause.edu/library/resources/2012 -horizon-report

O'English, L., \& McCord, S. (2006, April). Getting in on the game: Partnering with a university athletics department. portal: Libraries and the Academy, 6, 143-153.

Smale, M. A. (2011) Learning through quests and contests: Games in information literacy instruction. Journal of Library Innovation, 2, 36-55. Retrieved March 3, 2012, from http:// www.libraryinnovation.org/article/view/148/238

Sutton, L., \& Womack, H. D. (2006, March). Got game? Hosting game night in an academic library. College $\mathcal{E}$ Research Libraries News, 67, 173-176. Retrieved March 3, 2012, from http://crln.acrl.org/content/67/3/173.full.pdf+html

Wieder, B. (2011, April 24). Video-game rooms become the newest library space invaders. Chronicle of Higher Education. Retrieved February 27, 2012, from http://chronicle.com

Williams, J. M., \& Chimato, M. C. (2008). Gaming in D. H. Hill Library, NC State University. In A. Harris \& S. E. Rice (Eds.), Gaming in academic libraries: Collections, marketing, and information literacy (pp. 66-75). Chicago: Association of College and Research Libraries, A Division of the American Library Association.

Zitron, L., \& Drew, C. (2011, December). Get a clue: Partnering with student affairs on studentcentered outreach. College $\mathcal{E}$ Research Libraries News, 72, 636-641. Retrieved March 3, 2012, http://crln.acrl.org/content/72/11/636.full.pdf+html 
Angela M. Vanden Elzen received her MLIS from the University of Wisconsin-Milwaukee School of Information Studies. She is currently the interim web and reference librarian at the Lawrence University Seeley G. Mudd Library. Among other duties, she manages the library social media accounts, implements student outreach programming, and serves as advisor for the Lawrence University Gaming Club. Ms. Vanden Elzen has lectured on a variety of game-related topics and recently published the article, "Beyond a Fad: Why Video Games Should Be Part of 21st Century Libraries," with Dr. Kym Buchanan.

Jacob Roush graduated with a B.A. degree in biology from Lawrence University in 2012. While a student, he served as president of the Lawrence University Gaming Club and assisted in the planning and implementation of many library gaming events. He currently plays, writes, and studies theory on casual gaming and competitive eSports. For updates on his gaming, blogs, or links to other social media, find him on Twitter@dasbif. 